\title{
PENTINGNYA KEPUASAN KERJA
}

\author{
Sunarta \\ Fakultas Ekonomi Universitas Negeri Yogyakarta \\ sunarta@uny.ac.id
}

\begin{abstract}
Abstrak: Pentingnya Kepuasan Kerja. Upaya meraih kepuasan kerja penting baik bagi individu maupun organisasi. Ditinjau dari individu, kepuasan kerja tidak hanya berkaitan dengan pekerjaan yang menyenangkan, namun juga berhubungan dengan kebahagiaan dan kesehatan. Ditinjau dari organisasi, kepuasan kerja pegawai berhubungan dengan produktivitas, perilaku kerja positif, mengendalikan turn over dan kinerja. Kerja baik dalam pendekatan transaksional maupun relasional melibatkan dua pihak yaitu pegawai dan organisasi, sehingga kepuasan kerja dipengaruhi oleh faktor-faktor dari sisi pegawai dan organisasi. Upaya saling memahami menjadi penting untuk meraih kepuasan kerja yaitu bagaimana organisasi memahami kebutuhan, keinginan dan harapan pegawainya, serta bagaimana pegawai memahami tujuan bersama antara dirinya dengan organisasi. Komunikasi diperlukan sebagai sarana untuk meningkatkan pemahaman antara pegawai dan organisasi.
\end{abstract}

Kata kunci: Kepuasan Kerja, pegawai, organisasi dan produktivitas

\begin{abstract}
The Importance of Job Satisfaction. Efforts to achieve job satisfaction are important for both individuals and organizations. In terms of individuals, job satisfaction is not only related to pleasant work, but also related to happiness and health. In terms of organization, employee job satisfaction is related to productivity, positive work behavior, controlling turnover and performance. Work in both the transactional and relational approaches involves two parties, namely employees and the organization, so job satisfaction is influenced by factors in terms of employees and the organization. Efforts to understand each other are important for achieving job satisfaction, namely how the organization understands the needs, desires and expectations of its employees, and how employees understand the shared goals between themselves and the organization. Communication is needed as a means to increase understanding between employees and organizations.
\end{abstract}

Keyword: Job Satisfaction, employee, organization and productivity

\section{PENDAHULUAN}

Kepuasan kerja merupakan teori klasik dalam manajemen sumberdaya manusia. Literatur tentang kepuasan kerja sudah muncul sejak pertumbuhan era industri tahun 1930-an, namun tetap masih diperlukan sampai saat ini. Upaya meraih kepuasan kerja sangat penting baik bagi individu maupun organisasi. Kepuasan kerja tidak hanya mendorong perilaku positif seperti produktif, disiplin, patuh, inovatif, suka menolong, (Yahyagil, 2015) mengendalikan perilaku negatif kontra produktif seperti korupsi, pencurian, perusakan, dan keluar kerja (Greenidge, Devonish, \& Alleyne, 2014; Zhang \& Deng, 2014) namun juga berhubungan dengan kebahagiaan (Avent, 2007), kesehatan psikologis (Slaski \& Cartwright, 2003) dan kualitas kehidupan pekerja (Dhamija, Gupta, \& Bag, 2019). Kebahagiaan orang dalam bekerja tidak hanya berhubungan dengan gaji, namun bagaimana pegawai puas yang melibatkan aspek materi dan non materi (Avent, 2007). Kepuasan 
kerja tidak hanya merupakan imbal pendapatan, yaitu bagaimana kerja yang menyenangkan, baik dan bermakna (Arnoux-nicolas et al., 2016; Keles \& Findikli, 2016).

Setiap pegawai yang bekerja dalam organisasi, sejak diterima sampai memasuki masa pensiun ingin bekerja untuk memenuhi kebutuhan, keinginan, harapan dan kemampuan yang dimiliki. Melalui proses seleksi, pegawai yang diterima kemudian merencanakan jenjang karir, mendapatkan gaji/upah, berinteraksi sosial dalam organisasi. Perasaan (afektif) positif atas hasil kerja merupakan ungkapan atas apa yang ada dalam hati seorang pegawai dalam menilai sesuatu yang dilakukannya baik secara individu maupun bersama (Locke, 1969). Rasa puas atas proses dan hasil kerja yang diperoleh pegawai akan memperkuat komitmen dan etos kerja dalam mencapai tujuan organisasi (Ipekc \& Irmak, 2009). Sebaliknya apabila seorang pegawai merasa tidak memperoleh beberapa faktor penunjang dalam pelaksanaan kerja, maka kondisi tersebut berpotensi menyebabkan ketidakpuasan atas hasil kerjanya. Sebagai efek lanjutan dari situasi tersebut lambat laun akan mempengaruhi semangat dan hasil kerja baik secara kuantitas maupun kualitias.

Suatu organisasi yang dilanda perasaan tidak puas yang ditunjukkan oleh para pegawainya dalam bekerja dapat membawa dampak negatif sehingga dapat merugikan organisasi tersebut. Kerugian yang nyata dan langsung dirasakan adalah terjadinya penurunan moral kerja dan terganggunya layanan organisasi, baik kepada pihak internal maupun ekternal. Proses layanan organisasi yang terganggu akibat rendahnya semangat kerja yang ditunjukkan oleh para pegawainya, dapat menghambat jalannya sistem dan sub sistem bahkan supra sistem dalam skala yang lebih luas (Johari \& Yahya, 2016).

Organisasi yang tumbuh dan hidup di tengah-tengah lingkungan sosial, dalam mencapai tujuan ada kalanya mengalami situasi yang tidak bisa memuaskan keinginan semua anggotanya. Suatu rencana dan kebijakan yang ditetapkan organisasi akan selalu memiliki sisi positif dan negatif sehingga memiliki potensi penerimaan dan penolakan. Sikap penerimaan dan penolakan bagi setiap orang tergantung dari mana cara memandang persoalan yang ada. Perbedaan cara pandang yang berbeda-beda dalam menyikapi berbagai macam persoalan, memiliki potensi munculnya konflik antar individu dan kelompok terhadap organisasi. Semakin banyak elemen organisasi yang terlibat dalam usaha mencapai tujuan, maka akan semakin kompleks permsalahan yang dihadapi dengan potensi konflik yang kompleks pula. Hal ini mengingat karena organisasi beranggotakan dari bermacam-macam latar belakang, kepentingan, dan tujuan.

Dalam kehidupan sosial organisasi, interaksi antar individu dan kelompok konflik pasti akan muncul seiring perjalanan waktu. Konflik kadang-kadang bisa timbul karena perebutan sumber daya anggaran antar unit yang dapat meluas karena tingginya tingkat persaingan. Selain faktor anggaran, konflik peran dan jabatan seseorang dalam suatu oganisasi sudah hal yang jamak di 
semua level. Isu-isu keadilan organisasi juga tidak jarang mewarnai perjalanan organisasi yang menyebabkan konflik sehingga menyebabkan ketidakpuasan pegawai dalam bekerja (Hagemeister \& Volmer, 2017). Munculnya ketidak-puasan pegawai dalam bekerja disebabkan karena beberapa faktor seperti karakter perkerjaan, teman sejawat, kondisi kerja, gaji, upah, promosi, kepemimpinan, dan keadilan yang dirasakan.

Pegawai yang bekerja dengan giat dan memiliki sikap positif pada umumnya akan memperlihatkan tingkat kepuasan kerja yang tinggi dan begitu pula sebaliknya. Keterlibatan dan merasa dibutuhkan dalam menyelesaikan berbagai masalah pekerjaan, akan menghadirkan rasa puas pegawai dalam bekerja. Penghargaan ekstrinsik yang diberikan seperti gaji, upah, bonus, pujian, apresiasi, rasa hormat, dan bentuk empati lainnya yang bersifat intrinsik merupakan faktor kepuasan kerja. Ganjaran atau upah dalam bentuk materi bagi pegawai di banyak Negara, menempati urutan tertinggi sebagai faktor penentu kepuasan kerja.

Kepuasan kerja merupakan sikap (tindakan-kognisi), perasaan senang (ungkapan-afeksi), atau kesenjangan $(\mathrm{g} a b)$ antara apa yang telah diperoleh dengan apa yang diharapkan. Sikap senang yang ditunjukkan oleh seseorang dalam bekerja merupakan ekspresi karena apa yang menjadi tanggungjawabnya telah dijalankan dengan baik dan merasa puas atas hasil kerjanya. Sebaliknya apabila seseorang dalam bekerja tidak didukung oleh peralatan kerja yang memadai, lingkungan kerja yang tidak kondusif, dan rendahnya perhatian dari pimpinan, maka hal itu akan menimbulkan ketidakpuasan kerja. Ketidakpuasan pegawai di tempat kerja dikatakan oleh (Robin \& Judge, 2013) dapat mengarah pada tindakan keluar-meninggalkan organisasi, suara-aktif konstruktif, kesetiaanpasif optimis, dan pengabaian-pasif mengabaikan perintah dan larangan.

Organisasi yang dilanda perasaan tidak puas dalam bekerja dari para pegawainya dapat membawa dampak negatif sehingga merugikan organisasi. Kerugian yang nyata dan langsung dirasakan adalah terjadinya penurunan moral kerja dan terganggunya layanan organisasi, baik internal maupun ekternal. Tindakan mogok kerja, mosi tidak percaya, dan berbagai jenis tindakan negatif lain yang merugikan mungkin timbul sehingga perlu antisipasi sebagai solusi organiasasi. Keterlambatan dan kesalahan dalam menangani masalah internal akibat ketidakpuasan pegawai dalam bekerja, akan memperburuk situasi organisasi.

\section{Kepuasan Kerja}

Ide kepuasan kerja adalah hasil interaksi antara individu dan lingkungannya (Locke, 1969). Kepuasan kerja adalah sebuah konsep yang dapat menggambarkan bagaimana orang berpikir tentang pekerjaan, Berbasis Goal Setting Theory (Locke, 1969), kepuasan kerja adalah selisih antara tujuan individu dalam bekerja dengan kenyataan yang dirasakan. Menggunakan kata yang berbeda, dapat dinyatakan bahwa kepuasan dan ketidakpuasan kerja seorang pegawai dipengaruhi 
oleh selisih (discrappancy) antara apa yang telah didapatkan dengan apa yang diinginkan (Locke, 1969). Definisi tersebut dapat dimaknai bahwa kepuasan seorang pegawai dalam suatu organisasi akan timbul jika tidak ada kesenjangan antara apa yang diinginkan dengan apa yang diterima. Semakin jauh jarak antara apa yang diinginkan dengan yang diterima pegawai dalam suatu organisasi, maka munculnya rasa ketitidakpuasan terhadap pekerjaan yang dilakukan akan semakin kuat (King Jr, Lahiff, \& Hatfield, 2009).

Kepuasan kerja merupakan perasaan positif hasil dari evaluasi terhadap karakteristik pekerjaan (Robin \& Judge, 2013). Kepuasan kerja menurut (Locke, 1969) meliputi aspek afektif, kognitif dan perilaku. Perasaan (afektif) positif menggambarkan bahwa kepuasan kerja merupakan ungkapan atas apa yang ada dalam hati seseorang dalam menilai sesuatu yang dilakukannya baik secara individu maupun bersama. Kognitif (sensation, perception, conception) sebagaimana (Locke, 1969) menggambarkan bahwa pada dasarnya kepuasan kerja adalah sebuah ungkapan atas apa yang dirasakan (sensation), apa yang dipersepsikan (perception) dan apa yang dipikirkan (conception). Berdasarkan hasil pendefinisian tentang kepuasan kerja pegawai di dalam organisasi hampir semua definisi berkaitan dengan persepsi, sikap, perasaan, dan kesenangan atas suatu hasil kerja. Dengan kata lain maksud definisi tentang kepuasan kerja tidak ada yang berbeda secara ekstrim, melainkan hanya pada redaksi dan penekanan (stressing) saja.

Memperbincangkan teori tentang kepuasan kerja sangat banyak dibahas oleh para ahli dengan berbagai pendekatan ilmu masing-masing. Beberapa teori kepuasan kerja diantaranya seperti Goal Setting Theory dari (Locke, 1969), Vroom's Expectation Theory dari (Eerde, 1996), Equity Theory dari (Adams, 1963), dan Two Factor Theory oleh (Herzberg, 2003). Apabila menggunakan teori Goal Setting dari (Locke, 1969), maka kepuasan kerja pada dasarnya ditentukan oleh jarak antara apa yang diinginkan dan yang dimiliki seseorang dalam pekerjaan. Selanjutnya apabila mendasarkan pada pendekatan Vroom's Expectation Theory (Eerde, 1996) maka kepuasan kerja merupakan selisih antara apa yang seharusnya dengan kenyataan yang dirasakan. Kepuasan atau ketidakpuasan kerja muncul karena individu memiliki kemampuan dan kebutuhan.

Kebutuhan dalam hal ini tentu saja tidak hanya dalam bentuk materi (gaji dan upah) akan tetapi juga termasuk non materi seperti karir, prestasi, jabatan, kesempatan pengembangan, sosial, dan spiritual. Kebutuhan materi maupun non materi tersebut dipenuhi dengan cara bekerja, menggunakan kemampuan sehingga memberikan manfaat bagi individu dan organisasi. Pada saat bekerja, maka saat itulah individu mulai mempunyai harapan-harapan bahwa kebutuhan akan dipenuhi di tempat kerja. Ketidakpuasan muncul ketika ada kesenjangan antara harapan individu terhadap organisasi terhadap kebutuhan yang diterimanya setelah bekerja dalam organisasi. Kepuasan kerja merupakan perbandingan antara konstribusi individu dan imbalan yang 
diterimanyu. Jika dilihat dari aspek waktu, maka kepuasan kerja dapat dirsakan atau dapat terjadi pada saat imbalan yang diterima individu sama atau lebih besar dari harapan terhadap konstribusi yang diberikan individu terhadap organisasi.

Setiap orang yang bekerja akan melibatkan dua pihak yaitu dirinya sendiri dan organisasi, sehingga kepuasan kerjanya juga akan dipengaruhi oleh dukungan organisasi. Setiap orang juga bekerja menggunakan kemampuan yang dimilikinya untuk memberikan konstribusi bagi organisasi. Secara empiris telah banyak literatur yang membuktikan bahwa dukungan organisasional seperti gaji, insentif, kesempatan berkembang, karir, penghargaan, lingkungan sosial, dan lingkungan spiritual yang berpengaruh terhadap kepuasan kerja. Namun demikian, kepuasan kerja tidak hanya dipengaruhi oleh faktor dukungan organisasi yang diterima individu, namun juga perbandingan sosial seperti yang dijelaskan dalam Equity Theory (Adams, 1963).

Kepuasan kerja dalam pendekatan perbandingan sosial (Adams, 1963) menganggap bahwa kepuasan kerja tidak hanya melibatkan dua pihak yaitu individu pekerja dan pemberi kerja (organisasi) tetapi juga adanya perbandingan sosial. Teori keadilan organisasional muncul pada tahun 1960-an yang menjelaskan bahwa perilaku tidak hanya berkaitan dengan rasio imbal hasil terhadap sumberdaya namun juga dipengaruhi persepsi terhadap perbandingan sosial dan normanorma sosial. Teori ini memprediksi pengaruh kontribusi dan imbalan terhadap perilaku manusia dalam konteks lingkungan sosial. Individu-individu akan membuat perbandingan-perbandingan terhadap kontribusi dan imbalan, serta menghasilkan perubahan sikap dan perilaku (Adams, 1963). Ketidakadilan terjadi jika seseorang mempersepsikan dirinya mendapat imbalan lebih rendah dibandingkan dengan imbalan orang lain. Teori ini menjelaskan bahwa manusia untuk berperilaku tertentu dipengaruhi oleh persepsi keadilan yang diterima, seperti keadilan secara prosedural dan keadilan distributif.

Berdasarkan pendekatan teori keadilan (Adams, 1963), kepuasan seseorang akan sangat tergantung dari keadilan atas suatu situasi, dengan cara membandingkan input dan outcomes dari dirinya dengan orang lain dalam satu organisasi atau organisasi yang berbeda. Input dalam hal ini dapat dimaknai sebagai sesuatu yang berharga dan dirasakan individu sebagai bentuk sumbangan terhadap pekerjaan. Selanjutnya outcomes dapat dimaknai sebagai sesuatu yang berharga dan dirasakan oleh individu sebagai hasil dari pekerjaannya. Dengan demikian apabila perbandingan tersebut dirasakan cukup adil, maka kepuasan akan muncul dengan sendirinya. Keadilan prosedural mengacu pada prosedural atau mekanisme insentif jika individu berperilaku tertentu. Keadilan distributif mengacu pertukaran sumberdaya perusahaan sebagai perbandingan sosial antara individu satu terhadap individu yang lain. Keadilan dalam segala bentuknya, penting untuk meningkatkan 
kepuasan kerja (Tjahjono, 2010, 2011; Tjahjono, Palupi, \& Dirgahayu, 2015) sebagai faktor pendorong perilaku.

Keadilan mempersepsikan tentang perlakuan yang diterima seseorang dari orang lain. Pada umumnya para pegawai akan membandingkan masukan dan keluaran pekerjaan satu sama lain. Apabila perlakuan yang diterima menguntungkan, maka pegawai akan mengatakan dirinya diperlakukan secara adil, namun sebaliknya hal itu akan dikatakan sebagai suatu yang tidak adil jika perlakuan yang diterima dirasa merugikannya. Dalam menimbulkan persepsi tertentu seperti gaji atau upah, maka seseorang pada umumnya menggunakan tiga kategori sebagai referensi, yaitu orang lain, dirinya sendiri, dan sistem yang berlaku.

Literatur teoritis dan empiris tentang kepuasan kerja, baik dalam pendekatan Expectation Theory maupun Equity Theory dipengaruhi oleh pemahaman bekerja dalam pendekatan transaksional (Transactional Theory), dan relational (Sosial Exchange Theory), (Zoller, Muldoon, \& Muldoon, 2018). Bekerja dalam pendekatan transaksional seperti sebuah imbal hasil (pertukaran) sumberdaya, yakni individu menyediakan atas sejumlah barang atau jasa kemudian melalui pertukaran tersebut berharap apa yang diinginkan bisa diwujudkan. Bekerja dalam pendekatan relational (Social Exchange Theory) tidak hanya berkaitan dengan imbal hasil sumberdaya ekonomi dalam jangka pendek, namun juga berkaitan dengan hubungan sosial dalam jangka penjang.

Ukuran kepuasan kerja cukup bervariasi, sehingga yang penting sejauh mana ukuran dapat mengukur perasaan tentang pekerjaan (afektif atau emosional) atau kognisi (kognitif) tentang pekerjaan (Locke, 1969). Kepuasan kerja afektif mewakili perasaan emosional individu terhadap pekerjaan yang mencerminkan tingkat kesenangan atau kebahagiaan terhadap pekerjaan secara umum. Kemudian kepuasan kerja kognitif merupakan evaluasi objektif (rasional) berkaitan dengan berbagai aspek pekerjaan. Kepuasan kerja kognitif juga bersifat unidimensional yang berisi tentang evaluasi dari sisi ekstrinsik maupun intrinsik serta hubungan kerja. Kepuasan kerja kognitif juga dapat bersifat multidimensional yang meliputi evaluasi terhadap dua atau lebih aspek pekerjaan. Kepuasan kerja kognitif tidak menilai tingkat kesenangan atau kebahagiaan yang muncul dari pekerjaan, melainkan mengukur sejauh mana aspek-aspek pekerjaan tersebut dinilai oleh pekerja untuk mencapai kepuasan dibandingkan dengan tujuan yang ditetapkan sendiri dan dibandingkan dengan pekerjaan lainnya.

Kepuasan kerja dapat diukur dari kepuasan kerja secara umum (single global rating) dan penjumlahan (summation score) dari aspek-aspek pekerjaan (Khalilzadeh, Chiappa, \& Borujeni, 2013). Metode pengukuran diantaranya adalah skala wajah (faces scale), Minnesota satisfaction questionnaire (MSQ) dan job descriptive index (JDI). Mayoritas ukuran kepuasan kerja adalah self report dan didasarkan pada skala multi-item. Secara umum, kepuasan kerja diukur menurut "reaksi 
di tempat kerja", yang merupakan instrumen psikometri untuk penelitian organisasi. Selain itu, JDI (Khalilzadeh et al., 2013), juga merupakan salah satu ukuran kepuasan kerja kognitif yang mengukur kepuasan kerja dalam lima aspek seperti gaji, peluang promosi, hubungan rekan kerja, pengawasan, dan pekerjaan itu sendiri. Sebagian besar kuesioner JDI memerlukan tanggapan singkat dari "ya", "tidak", atau "saya tidak tahu". Sebagian besar survei yang lain menggunakan kuesioner skala Likert untuk pengukuran. Penggunaan skala nominal,mudah digunakan dan dimengerti oleh pekerja, sedangkan penggunaan skala Likert membantu peneliti untuk mendapatkan analisis yang lebih fleksibel untuk data kategorikal dan interval dibadingkan data nominal.

Kuesioner kepuasan kerja lainnya meliputi Minnesota Satisfaction Questionnaire (MSQ), Job Satisfaction Survey (JSS), dan Skala Wajah (faces scale) (Khalilzadeh et al., 2013). Skala MSQ mengukur kepuasan dari aspek lingkungan kerja, peluang berkarir, kebebasan melakukan penilaian sendiri, penghargaan intrinsik dalam menyelesikan tiap pekerjaan secara baik, dan keinginan untuk berprestasi. JDI mengukur lima aspek: (1) berkaitan dengan pekerjaan meliputi tanggung jawab, minat, dan peluang pertumbuhan, (2) kualitas pengawasan meliputi bantuan teknis dan dukungan pengawas, (3) hubungan dengan rekan kerja, (4) peluang promosi, kesempatan untuk perkembangan karir, dan jabatan, serta (5) imbal hasil pendapatan, yakni kecukupan pembayaran dan persepsi keadilan dibandingkan orang lain.

\section{Upaya Meraih Kepuasan Kerja}

Stimulus-Organism-Respon menjelaskan bahwa stilumus eksternal (lingkungan eksternal) mempengaruhi persepsi, selanjutnya persepsi mempengarui sikap (puas dan tidak puas) atas hasil kerja dan perilaku kerja. Berdasarkan perpektif perilaku sosial, kepuasan kerja dipengaruhi oleh faktor lingkungan eksternal dan internal individu seperti pikiran dan emosi. Sebagaimana dikatakan oleh (Herzberg, 2003) bahwa faktor lingkungan eksternal meliputi gaji, kondisi kerja, kebijakan dan administrasi, pengawasan, teknis, hubungan antar pribadi penyelia, prestasi, pengakuan (apresiasi), penghargaan, promosi pangkat, pekerjaan itu sendiri, tanggungjawab, komunikasi dan informasi. Sedangkan faktor internal/individu berkaitan dengan persepsi dan emosi. Secara umum, suasana hati dan emosi di tempat kerja sebenarnya juga berhubungan dengan kepuasan kerja, akan tetapi suasana hati cenderung memiliki sifat waktu yang lebih lama.

Setidaknya ada dua klasifikasi sebagaimana dikatakan oleh (Herzberg, 2003) yakni faktor hygien atau penyebab ketidakpuasan dan faktor motivator sebagai penyebab kepuasan. Faktor hygien sebagai faktor penyebab ketidakpuasan dalam bekerja bersifat ektrinsik, sedangkan faktor pemuas sebagai pendorong (motivator) dalam bekerja bersifat instrinsik. Faktor ekstrinsik sangat sarat dengan hal-hal yang bersifat fisik atau meteriil sedangkan faktor instrinsik lebih bersifat 
pujian, sanjungan, pengakuan, dan prestasi. Faktor pemotivasian (motivator) merupakan intrinsic factors meliputi dorongan untuk berprestasi, kemajuan, kesempatan berkembang, tanggung jawab, dan pekerjaan itu sendiri. Faktor-faktor pemeliharaan (hygiene factors) merupakan extrinsic factors, yang meliputi masalah penggajian, pengupahan, kebijakan, keamanan kerja, pengawasan, administrasi, kondisi kerja, dan status pegawai.

Oleh Herzberg disimpulkan bahwa kepuasan kerja (job satisfaiers) selalu dihubungkan dengan isi jenis pekerjaan (job content) dan ketidak-puasan kerja (job dissatisfaiers) selalu disebabkan karena hubungan pekerjaan tersebut dengan aspek-aspek di sekitar yang berhubungan dengan pekerjaan (job context). Sedangkan kepuasan-kepuasan dalam bekerja oleh Herzberg dinamakan motivator dan ketidak-puasan dinamakan faktor hygiene, sehingga keduanya dikenal dengan teori motivasi dua faktor Herzberg. Dalam teori Herzberg, pegawai harus diberi pekerjaan yang lebih menantang, mengarah pada pekerjaan yang menuntut keahlian sehingga kemampuannya dapat berkembang dan mudah dimotivasi. Sebagai faktor kepuasan kerja, motivator dapat berbentuk prestasi, promosi, kenaikan pangkat, serta penghargaan lain yang dapat memotivasi pegawai dalam bekerja. Menurut Locke (Locke, 1969), kepuasan kerja melipusi aspek rasional dan irrasional (emosi). Berbasis pendekatan Utilitarianism, setiap orang selalu berusaha memaksimalkan kepentingan diri dan kelompoknya. Manusia hanya akan bertindak apabila diperkirakan dia akan mendapatkan imbalan. Efek endowment (imbal hasil) sebagai fakta bahwa orang seringkali meminta (mengharapkan) jauh lebih banyak dibandingkan dengan yang individu berikan untuk mendapatkannya.

Kepuasan kerja, jika dilihat dari sisi individu pegawai maupun organisasi, maka masingmasing akan cenderung untuk memaksimalisasi kepentingan sendiri-sendiri. Pegawai akan cenderung mengharapkan jauh lebih banyak dibandingkan dengan yang diberikan untuk mendapatkannya. Aetiap pegawai akan mengevaluasi reaksi-reaksi (kesenangan atau enyesalan) yang diperkirakannya pada sebuah peristiwa atau situasi di masa yang akan datang. Penyesalan merupakan emosi yang disebabkan karena membandingkan hasil (state of event) yang ada dengan state of a foregone choise. Teori ketakutan akan penyesalan atau disebut penyesalan berhubungan dengan reaksi emosional yang dialami seseorang setelah menyadari bahwa mereka telah melakukan kesalahan dalam penilaian.

Berkaitan dengan respon emosional pegawai, pegawai menjadi secara emosional terpengaruh oleh kondisi lingkungan organisasi yang tidak sesuai dengan harapannya Sehingga, pegawaimengevaluasi konstribusinya sebagai cara untuk menghindari rasa menyesal. Pegawai yang merasa telah memberikan konstribusi pada organisasi, namun memperoleh imbal hasil yang tidak sesuai harapan akan mengevaluasi peran. Selain itu, pegawai lebih cenderung hanya beperilaku 
sesuai tanggungjawabnya (in role) dan mengurangi perilaku diluar (ekstra role) tanggungjawabnya. Penyesalan merupakan rasa frustasi atas sebuah tindakan yang telah diambil dengan hasil yang kurang dari apa yang diharapkan atau kegagalan untuk bertindak ketika hasil positif diperoleh.

Kepuasan kerja pegawai akan muncul apabila faktor-faktor pengganggu atau penghambat seperti karakter perkerjaan, teman sejawat, kondisi kerja, gaji, upah, promosi, kepemimpinan, dan keadilan atas hak-hak pegawai bisa terpenuhi sesuai dengan harapan (ekspektasi). Semua pegawai yang bekerja dalam suatu organisasi, pada umumnya akan mengalami proses rekruitmen, seleksi, penempatan, dan peningkatan karir sesuai jalur yang telah diprogramkan. Dalam proses seleksi inilah pegawai yang diterima biasanya menginginkan jenjang karir yang tinggi, sistem penggajian yang adil (Stringer, Didham, \& Theivananthampillai, 2011) dan perlakuan pimpinan yang manusiawi merupakan harapan selama bekerja. Seorang pegawai selama bekerja, dapat merasa puas bahkan sangat puas pada satu aspek tertentu namun sangat mungkin tidak puas pada satu atau lebih aspek yang lain.

Ganjaran yang diberikan kepada pegawai dapat berupa gaji, upah, bonus, dan kesejahteraan lain yang bersifat ekstrinsik, serta ganjaran yang berupa pujian, penghargaan, apresiasi, rasa hormat, dan bentuk empati lainnya yang bersifat instrinsik (Stringer et al., 2011). Ganjaran atau upah dalam bentuk materi bagi pegawai di banyak Negara, menempati urutan tertinggi sebagai faktor kepuasan kerja. Faktor lain dalam bentuk non materi seperti pujian dan apresiasi dapat memberikan pengaruh positif dalam bekerja.

Jenis pekerjaan yang secara mental menantang juga berhubungan dengan kepuasan kerja (Robin \& Judge, 2013). Pegawai ada kalanya mengalami rasa bosan dalam bekerja, hal ini akibat dari jenis pekerjaan yang dilakukanya monoton dari waktu ke waktu bahkan banyak pegawai yang sudah puluhan tahun sejak pertama diangkat sebagai pegawai hanya mengerjakan satu jenis pekerjaan yang sama. Pegawai dengan karakter tertentu seringkali akan merasa puas dalam bekerja apabila bisa menyelesaikan pekerjaan yang menantang. Semakin menantang jenis pekerjaan yang diberikan kepadanya, semakin ingin segera menyelesaikan pekerjaan tersebut. Pegawai dengan karakter seperti ini memiliki motivasi dan rasa ingin tahu yang tinggi dalam bekerja. Secara ekstrim para pegawai yang memiliki karakter tersebut menganggap bahwa pekerjaan yang hasil kerjanya sudah dapat diperkirakan sebelumnya tidak memberikan tingkat kepuasan yang tinggi dibandingkan pekerjaan yang sulit dan menantang.

Dukungan organisasi dalam menciptakan lingkungan kerja yang kondusif melalui penyediaan peralatan kerja, fasilitas ibadah, kantin, ruang kerja yang terang, bersih, sejuk, dan sistem ventilasi udara yang baik dapat mendukung teciptanya perasaan senang dan puas para pegawai dalam bekerja (Robin \& Judge, 2013). Dalam situasi tertentu kondisi kerja yang terlalu 
dingin, terlalu panas, terlalu ramai, terlalu sepi, terlalu gelap, dan terlalu terang bisa menimbulkan konflik antar pegawai yang menyebabkan ketidakpuasan dalam bekerja. Idealnya kondisi kerja yang bisa mengakomodir semua kepentingan adalah keadaan yang biasa-biasa saja, tidak terlalu dingin tetapi tidak terlalu panas, tidak terlalu gelap tetapi tidak terlalu terang dan seterusnya kecuali jenis-jenis pekerjaan tertentu yang memang mensyaratkan hal tersebut.

Kerjasama antar pegawai dalam bekerja dapat mendukung keberhasilan kerja. Pegawai yang bekerja dalam suasana keakrapan dan saling membutuhkan satu sama lain, akan melengkapi perasaan senang dan puas dalam bekerja. Teman kerja pada dasarnya adalah seperti keluarga dalam arti terbatas pada hal-hal yang bersinggungan dengan pekerjaan di tempat kerja. Sikap ramah, persahabatan, kehangatan, dan perhatian yang diterima/dirasakan oleh para pegawai dari para atasan/pimpinan sebenarnya bisa membangkitkan perasaan puas terhadap hasil kerja yang dilakukanya (Robin \& Judge, 2013).

Beberapa pegawai sangat menikmati pekerjaannya karena sesuai dengan harapan pada saat melamar. Begitu pula pegawai yang lain ada yang tidak puas dengan pekerjaan dan hasil kerjanya karena yang dikerjakan tersebut tidak sesuai dengan minatnya. Jenis pekerjaan yang tersedia di dalam organisasi sudah barang tentu terbatas, sedangkan para pegawai yang bekerja memiliki kepribadian yang sangat luas. Pegawai dengan minat dan keterampilan tertentu akan memiliki tingkat capaian kerja yang optimal apabila yang dikerjakannya tersebut kongruen dengan kepribadian yang dimilikinya (Robin \& Judge, 2013).

Komunikasi atasan-bawahan merupakan pengaruh penting terhadap kepuasan kerja di tempat kerja (Robin \& Judge, 2013). Cara bawahan memandang perilaku atasan dapat secara positif atau negatif mempengaruhi kepuasan kerja. Perilaku komunikasi seperti ekspresi wajah, kontak mata, ekspresi vokal, dan gerakan tubuh sangat penting untuk hubungan atasan-bawahan. Pesan nonverbal memainkan peran sentral dalam interaksi antarpribadi sehubungan dengan pembentukan kesan, penipuan, ketertarikan, pengaruh sosial, dan emosional. Kedekatan nonverbal dari atasan membantu meningkatkan keterlibatan interpersonal dengan bawahan yang berdampak pada kepuasan kerja. Cara pengawas berkomunikasi dengan bawahan secara non-verbal dapat lebih penting daripada konten verbal.

Individu yang tidak suka dan berpikir negatif tentang atasannya kurang bersedia untuk berkomunikasi atau memiliki motivasi untuk bekerja sedangkan individu yang menyukai dan berpikir positif tentang atasannya lebih cenderung berkomunikasi dan puas dengan pekerjaan dan lingkungan kerjanya. Seorang pengawas yang menggunakan kedekatan non-verbal, keramahan, dan jalur komunikasi terbuka lebih mungkin untuk menerima umpan balik positif dan kepuasan kerja yang tinggi dari bawahan. Sebaliknya, seorang supervisor yang antisosial, tidak ramah, dan tidak 
mau berkomunikasi secara alami akan menerima umpan balik negatif dan menciptakan kepuasan kerja yang rendah pada bawahan di tempat kerja.

Sedikitnya terdapat empat respon ketidakpuasan yang dirasakan oleh pegawai di tempat kerja, yaitu (Robin \& Judge, 2013): (a) keluar, (b) suara, (c) kesetiaan, dan (d) pengabaian. Respon keluar mengindikasikan atas perilaku pegawai dalam bersikap untuk keluar atau bertahan. Keputusan untuk bertahan masih sangat mungkin jika ada posisi baru yang menjanjikan masa depannya. Respon suara, mengarahkan perilaku untuk secara aktif berkontribusi dalam upaya ikut memperbaiki situasi dan keadaan dalam organisasi dengan berbagai kesempatan termasuk memberikan masukan dan saran kepada pimpinan atas masalah yang dihadapi. Respon kesetiaan, cenderung bersifat pasif tetapi tetap tetap menaruh harapan yang besar agar kondisi akan segera berubah kearah yang lebih baik. Respon pengabaian, pegawai cenderung pasif dan membiarkan walaupun kondisi organisasi semakin memburuk dan diperparah oleh adanya tingkat kehadiran rendah, serta minimnya usaha dalam mengurangi kesalahan kerja.

\section{KESIMPULAN}

Kepuasan kerja merupakan sikap (tindakan-kognisi), perasaan senang (ungkapan-afeksi), atau kesejangan antara apa yang telah diperoleh dengan apa yang telah didapatkan. Selain itu, bagi para pegawai kepuasan kerja juga merupakan sikap dari setiap individu mengenai pekerjaan yang dikerjakan dalam setiap harinya. Sikap positif yang ditunjukkan dalam bekerja akan memberikan gambaran bagi tingkat kepuasan kerjanya. Pegawai yang bekerja dengan sikap senang dan nyaman di tempat kerja akan memberikan kontribusi kinerja optimal dan begitu pula sebaliknya.

Kepuasan kerja dipengaruhi oleh lingkungan eksternal dan internal individu. Upaya saling memahami menjadi penting yaitu bagaimana organisasi memahami kebutuhan, keinginan dan harapan pegawainya, serta bagaimana pegawai memahami tujuan bersama antara dirinya dengan organisasi. Komunikasi menjadi penting sebagai sarana untuk meningkatkan pemahaman antara pegawai dan organisasi. Perkembangan teknologi komunikasi dan informasi di Era digital memfasilitasi komunikasi untuk meningkatkan pemahaman antara pegawai dan organisasi, sehingga secara tidak langsung berpotensi meningkatkan kepuasan kerja pegawai.

Langkah nyata yang bisa dilakukan oleh para manajer dan pimpinan organisasi dalam mewujudkan dan mempertahankan kepuasan kerja yang dirasakan oleh setiap pegawai salah satunya adalah menunaikan semua kewajiban organisasi yang merupakan hak-hak yang harus diterima pegawai. Dukungan dalam menciptakan lingkungan kerja dan peralatan kerja yang memadai juga hal penting dalam mewujudkan kepuasan kerja bagi setiap pegawai dalam bekerja. Masih banyak faktor pembentuk terwujudnya kepuasan kerja pegawai, namun jika ada upaya positif 
dari para manajer dan pimpinan organisasi dalam memenuhinya, maka hal itu merupakan bentuk dukungan dalam upaya mengeliminir munculnya perasaan tidak puas terhadap hasil kerja..

\section{DAFTAR PUSTAKA}

Adams, J. S. (1963). Toward an Understanding of Inequity. Journal of Abnormal And, Social Psychology, 67(5), 422-436.

Arnoux-nicolas, C., Sovet, L., Lhotellier, L., Fabio, A. Di, Bernaud, J., Torre, T., \& Arnouxnicolas, C. (2016). Perceived Work Conditions and Turnover Intentions : The Mediating Role of Meaning of Work. Psychol, 7(May), 1-9. https://doi.org/10.3389/fpsyg.2016.00704

Avent, C. (2007). Happiness is job satisfaction. In Education \& Trai (p. 106).

Dhamija, P., Gupta, S., \& Bag, S. (2019). Measuring of job satisfaction : the use of quality of work life factors. Benchmarking: An International Journal. https://doi.org/10.1108/BIJ-06-20180155

Eerde, W. Van. (1996). Vroom's Expectancy Models and Work-Related Criteria: A MetaAnalysis. Journal of Applied Psychology, 81(5), 575-586.

Greenidge, D., Devonish, D., \& Alleyne, P. (2014). The Relationship Between Ability-Based Emotional Intelligence and Contextual Performance and Counterproductive Work Behaviors : A Test of the Mediating Effects of Job Satisfaction. Human Performance, 27(3), 37-41. https://doi.org/10.1080/08959285.2014.913591

Hagemeister, A., \& Volmer, J. (2017). Do social con fl icts at work a ff ect employees ' job satisfaction? The moderating role of emotion regulation. International Journal of Conflict Management. https://doi.org/10.1108/IJCMA-11-2016-0097

Herzberg, F. (2003). One More Time: How Do You Motivate Employees? Harvard Business Review, 1-11.

Ipekc, E., \& Irmak, S. (2009). Path analysis of organizational commitment, job involvement and job satisfaction in Turkish hospitality industry. Tourism Review, 64(1), 4-16. https://doi.org/10.1108/16605370910948821

Johari, J., \& Yahya, K. K. (2016). Job Characteristics, Work Involvement, And Job Performance Of Public Servants. European Journal of Training and Development, 40(7).

Keles, H. N., \& Findikli, M. A. (2016). Global Journal of Business , Economics and Management stress and intention to leave. Global Journal of Business, Economics and Management, 6(2), 61-69. https://doi.org/10.18844/gjbem.v6i2.1370

Khalilzadeh, J., Chiappa, G. Del, \& Borujeni, H. Z. (2013). Methodological approaches to job satisfaction measurement in hospitality firms. International Journal of Contemporary Hospitality Management, 25(6), 865-882. https://doi.org/10.1108/IJCHM-05-2012-0067

King Jr, W. C., Lahiff, J. M., \& Hatfield, J. D. (2009). A discrepancy theory of the relationship between communication and job satisfaction This study found moderate differences in correlations between communication and job satisfaction using a discrepancy framework when high , as opposed to low , valence rewa. Communication Research Reports,5(1), 37-41. https://doi.org/10.1080/08824098809359798

Locke, E. A. (1969). W h a t is Job Satisfaction? Organizational Behavior And Human Performance, 336, 309-336.

Robin, S. P., \& Judge, T. A. (2013). Organizational behavior (15th ed.). New Jersey: Pearson 
Education, Inc., Prentice Hall.

Slaski, M., \& Cartwright, S. (2003). Emotional intelligence training and its implications for stress , health and performance. Stress and Health, 239(October 2002), 233-239. https://doi.org/10.1002/smi.979

Stringer, C., Didham, J., \& Theivananthampillai, P. (2011). Motivation , pay satisfaction , and job satisfaction of front-line employees. Qualitative Research in Accounting \& Managemen, 8(2), 161-179. https://doi.org/10.1108/11766091111137564

Tjahjono, H. K. (2010). The extension of two-factor model of justice: hierarchical regression test and sample split. China-USA Business Review, 9(7), 39.

Tjahjono, H. K. (2011). The configuration among social capital, distributive and procedural justice and its consequences to individual satisfaction. International Journal of Information and Management Sciences, 87-93.

Tjahjono, H. K., Palupi, M., \& Dirgahayu, P. (2015). Career Perception at the Republic Indonesian Police Organization Impact of Distributive Fairness , Procedural Fairness and Career Satisfaction on Affective Commitment. International Journal of Administrative Science and Organization, 22(2).

Yahyagil, M. Y. (2015). Values, feelings, job satisfaction and well-being: the Turkish case. Management Decision, 53(10).

Zhang, L., \& Deng, Y. (2014). Guanxi with Supervisor and Counterproductive Work Behavior: The Mediating Role of Job Satisfaction. Jornal of Business Ethics, (2013). https://doi.org/10.1007/s10551-014-2438-7

Zoller, Y. J., Muldoon, J., \& Muldoon, J. (2018). Illuminating the principles of social exchange theory with Hawthorne studies theory. Journal of Management History. https://doi.org/10.1108/JMH-05-2018-0026

\section{UCAPAN TERIMA KASIH}

Penulis mengucapkan terima kasih kepada redaksi jurnal Efisiensi jurusan Pendidikan Administrasi Fakultas Ekonomi Univesitas Negeri Yogyakarta yang telah memberi kesempatan untuk menuangkan gagasan dan pikiran tentang pentingnya kepuasan kerja dalam suatu organisasi. Tidak lupa pula penulis ucapkan terima kasih kepada rekan-rekan mahasiswa program doktor Ilmu Ekonomi Universitas Islam Indonesia yang telah memberikan masukan dan sarannya demi penerbitan artikel ini.

\section{PROFIL PENULIS}

Penulis adalah dosen Jurusan Manajemen, Program Studi Manajemen Pemasaran D-4, Fakultas Ekonomi Univesitas Negeri Yogyakarta. Saat ini sedang menyelesaikan program doktor Ilmu Ekonomi di Fakultas Ekonomi Universitas Islam Indonesia Yogyakarta. 